\title{
A Method for Combining Isolates of Phytophthora sojae to Screen for Novel Sources of Resistance to Phytophthora Stem and Root Rot in Soybean
}

R. L. Matthiesen, Department of Plant Pathology and Microbiology, Iowa State University, Ames 50011; N. S. Abeysekara, Department of
Plant and Soil Sciences, University of Delaware, Newark 19716; J. J. Ruiz-Rojas, R. M. Biyashev, and M. A. Saghai Maroof, Department of
Crop and Soil Environmental Sciences, Virginia Tech, Blacksburg 24060; and A. E. Robertson, Department of Plant Pathology and Microbiology, Iowa State University

\begin{abstract}
Matthiesen, R. L., Abeysekara, N. S., Ruiz-Rojas, J. J., Biyashev, R. M., Saghai Maroof, M. A., and Robertson, A. E. 2016. A method for combining isolates of Phytophthora sojae to screen for novel sources of resistance to Phytophthora stem and root rot in soybean. Plant Dis. 100:1424-1428.

Soybean cultivars with specific single resistance genes (Rps) are grown to reduce yield loss due to Phytophthora stem and root rot caused by the oomycete pathogen Phytophthora sojae. To identify novel Rps loci, soybean lines are often screened several times, each time with an isolate of $P$. sojae that differs in virulence on various $R p s$ genes. The goal of this study was to determine whether several isolates of $P$. sojae that differ in virulence on Rps genes could be combined into a single source of inoculum and used to screen soybean lines for novel Rps genes. A set of 14 soybean differential lines, each carrying a specific Rps gene, was inoculated with three isolates of $P$. sojae, which differed in virulence on 6 to 10 Rps genes, individually or in a 1:1:1 mixture. Inoculum

containing the 1:1:1 mixture of isolates was virulent on 13 Rps genes. The mixed-inoculum method was used to screen 1,019 soybean accessions in a blind assay for novel sources of resistance. In all, $17 \%$ of Glycine $\max$ accessions and $11 \%$ of $G$. soja accessions were resistant ( $\leq 30 \%$ dead plants), suggesting that these accessions may carry a novel Rps gene or genes. Advantages of combining isolates into a single source of inoculum include reduced cost, ability to screen soybean germplasm with inoculum virulent on all known Rps genes, and ease of identifying novel sources of resistance. This study is a precursor to identifying novel sources of resistance to $P$. sojae in soybean using RXLR effectors.
\end{abstract}

Phytophthora stem and root rot (PRR), caused by the oomycete Phytophthora sojae Kaufm. \& Gerd. (syn. P. megasperma f. sp. glycinea), is an economically important disease of soybean (Glycine $\max ($ L.) Merrill), significantly affecting soybean production worldwide (Tyler 2007). Soybean yield loss caused by PRR averaged 43 million bushels annually in the United States (2006 to 2009) (Koenning and Wrather 2010) and more than $\$ 1$ billion per year worldwide (Tyler 2007). Yield loss can increase substantially in years with abundant rainfall and warm soil temperatures in the spring (Robertson et al. 2009).

$P$. sojae is a soilborne pathogen that survives from one season to the next as oospores in infested crop residue and soil. Oospores are formed as a result of sexual reproduction. In flooded conditions, oospores germinate and give rise to sporangia from which zoospores (asexual reproduction) are produced. Infection of soybean occurs primarily via these zoospores that are chemotactically attracted to soybean roots, where they encyst, germinate, and infect the plant (Dorrance et al. 2007).

PRR is primarily managed by incorporating single resistance genes (Rps) into commercial soybean cultivars (Grau et al. 2004; Stewart et al. 2014). Twenty genes have been found to confer resistance to PRR, with five of those Rps genes identified in the past 5 years (Demirbas et al. 2001; Diers et al. 1992; Fan et al. 2009; Gordon et al. 2006; Lin et al. 2013; Lohnes and Schmitthenner 1997; Sandhu et al. 2005; Sun et al. 2011; Weng et al. 2001; Wu et al. 2011; Zhang et al. 2013; Zhu et al. 2007). Only a few of these genes (Rps 1a, Rps 1b, Rps 1c, Rps 1k, Rps 3a, and Rps 6) have been

\section{Corresponding author: A. E. Robertson; E-mail: alisonr@iastate.edu}

*The $\boldsymbol{e}$-Xtra logo stands for "electronic extra" and indicates that one supplementary table is published online.

Accepted for publication 22 January 2016.

http://dx.doi.org/10.1094/PDIS-08-15-0916-RE

(C) 2016 The American Phytopathological Society incorporated separately into soybean germplasm for commercial use (Dorrance and Schmitthenner 2000; Dorrance et al. 2007). More recently, a few cultivars with two Rps genes have become commercially available for farmers to plant; for example, $R p s 1 \mathrm{c}$ pyramided with Rps $1 \mathrm{k}$, Rps $1 \mathrm{k}$ with Rps 6, or Rps $1 \mathrm{k}$ with $R p s 7$ (Slaminko et al. 2010).

For each Rps gene, there is a corresponding avirulence (Avr) gene (Tyler 2007). Avr genes encode proteins (i.e., effectors) that interact with proteins encoded by Rps genes, resulting in activation of defense responses in the plant and plant resistance (Jiang and Tyler 2012; Staskawicz et al. 1995). These effectors have an N-terminal amino acid sequence motif (known as RxLR) that is required for effector translocation into the plant cell (Song et al. 2013; Tyler 2009). Several of these Avr genes have been molecularly cloned and all have been shown to encode secreted $A v r$ proteins in the RxLR superfamily (Dong et al. 2011; Jiang and Tyler 2012). Individual isolates of $P$. sojae might have one or more Avr genes corresponding to known $R p s$ genes (Dong et al. 2011; May et al. 2002). Isolates of $P$. sojae are classified into pathotypes (previously referred to as races) based on their ability to cause disease (virulence) on a standard set of differentials composed of soybean lines, each of which contain a different $R p s$ gene (Robertson et al. 2009). The pathotype of a $P$. sojae isolate is represented as a virulence formula that indicates which $R p s$ gene or genes show a susceptible response, such as a brown lesion spreading from the inoculation site (i.e., virulence) to that isolate.

New pathotypes of $P$. sojae continue to evolve and the population of the pathogen in an individual field can be extremely diverse (Dorrance et al. 2003; Malvick and Grunden 2004; Robertson et al. 2009). Consequently, a single Rps gene that once was effective may be rendered ineffective against the same $P$. sojae isolates present in an individual field within a few years (Grau et al. 2004; Stewart et al. 2014). Because the pathotypic diversity of $P$. sojae is on the rise in the United States, soybean breeders continually screen germplasm for novel Rps genes.

The hypocotyl inoculation test is the traditional method of screening soybean lines or populations for resistance to $P$. sojae (Dorrance et al. 2004; Schmitthenner 1985). Kaufmann and Gerdemann (1958) compared several inoculation methods and demonstrated that hypocotyl 
inoculation clearly distinguished between resistant and susceptible plants. Moreover, this method had an added advantage, in that it reduced confusion due to poor germination of seed, a factor that often needs to be considered when screening germplasm accessions. Using the hypocotyl inoculation method, germplasm is typically screened several times using a different isolate of $P$. sojae with a known pathotype in each screen (Burnham et al. 2003; Dorrance and Schmitthenner 2000; Zhang et al. 2010). Thus far, no single P. sojae isolate is virulent on all known Rps genes; therefore, multiple isolates varying in pathotype need to be used to identify new sources of resistance to PRR (Gordon et al. 2007). In most cases, an average of two to eight isolates are used individually to inoculate plants (Burnham et al. 2003; Dorrance and Schmitthenner 2000; Gordon et al. 2007; Zhang et al. 2010), and soybean lines or populations are screened at least two times per isolate (Dorrance and Schmitthenner 2000; Zhang et al. 2010). Screening multiple isolates individually requires a large quantity of seed, additional laboratory materials, increased greenhouse space, and significantly more time.

Identifying novel sources of resistance to PRR is a key component of soybean breeding as a means of managing PRR. The possibility of combining $P$. sojae isolates with varying pathotypes into a single source of inoculum that could be used to identify novel Rps genes has not been evaluated. The objectives of this study were to determine whether (i) isolates of $P$. sojae with different pathotypes could be combined to produce a single source of inoculum that was virulent on 13 of the 14 standard differential lines and, thus, to almost all known Rps genes for which differential lines are available; and (ii) this source of inoculum could be used to screen soybean lines for novel sources of resistance to $P$. sojae.

\section{Materials and Methods}

$P$. sojae isolates. Three isolates of $P$. sojae were used in this study: PT2004 C2.S1 (pathotype 1a, 1b, 1c, 1d, 1k, 2, 3c, 4, 6, 7) (Wang et al. 2012) was received from Dr. Brett Tyler (Virginia Tech), R7-2a (pathotype 1d, 2, 3a, 5, 6, 7) was received from Dr. Anne Dorrance (Ohio State University), and 1005-2.9 (pathotype 1a, 1b, 1c, 1k, 3b, 7) was recovered from a soil sample collected in 2009 from a soybean rotation study in Iowa (Stewart et al. 2014).

Inoculum preparation and inoculation method. $P$. sojae isolates were grown on separate plates containing half-strength V8 juice media amended with neomycin sulfate $(50 \mu \mathrm{g} / \mathrm{ml})$ and chloramphenicol $(10 \mu \mathrm{g} / \mathrm{ml})(\mathrm{DV} 8)$ for 5 to 7 days at $23^{\circ} \mathrm{C}$ in the dark. Inoculum was prepared from colonized DV8 plates using syringes to make an agar-based slurry of the pathogen, as outlined by Dorrance et al. (2004). Seven-day-old plants were inoculated with inoculum using the hypocotyl inoculation method described by Dorrance et al. (2004), in which approximately 0.2 to $0.5 \mathrm{ml}$ of inoculum slurry was placed in a slit made in the hypocotyl of the plants being tested.

Virulence assessment. The pathotype of each isolate was determined by assessing its virulence on a set of 14 soybean differential lines that each have a specific Rps gene (Table 1). Simultaneously, a 1:1:1 mixture of the three isolates was pathotyped on the same set of differential lines. 'Sloan' soybean (background 'Williams'), which has no Rps genes, was included with each differential set to confirm the pathogenicity of each isolate. Ten seeds of each soybean line were grown for 7 days in 8 -oz polystyrene cups filled with coarse vermiculite at $25^{\circ} \mathrm{C}$ in the greenhouse. All seedlings were inoculated using the hypocotyl inoculation method (Dorrance et al. 2004). Immediately after inoculation, plants were kept in a dew chamber at $25^{\circ} \mathrm{C}$ for $24 \mathrm{~h}$ in the dark before being placed in the greenhouse. Plants were scored 7 days postinoculation. The isolate was considered virulent on an Rps differential line when $>70 \%$ of seedlings were killed and avirulent when $\leq 30 \%$ of the seedlings died (Table 2). The experiment was replicated three times.

Plant material. Soybean germplasm used in this study to screen for $P$. sojae resistance consisted of 490 accessions of Glycine max and 529 accessions of $G$. soja. The Maroof lab chose lines based on background information of each line according to the Germplasm Resources Information Network (GRIN) database (http://www.arsgrin.gov), Dorrance and Schmitthenner (2000), and Pazdernik et al.
(1997). In the GRIN database, over 14,000 G. max accessions have been tested for reaction to $P$. sojae. Of the 490 selected $G$. max accessions used in our study, 356 had been screened previously and showed a resistance reaction to at least 3 pathotypes, and up to 11 pathotypes for some accessions. The parents of the soybean Nested Association Mapping populations, 40 G. $\max$ accessions, were also chosen for this study. The remaining $94 G$. $\max$ accessions we screened were chosen arbitrarily, with no regard for resistance to the pathogen. Of the 1,179 G. soja accessions in the GRIN database, $P$. sojae screening data for 448 accessions were available from previous reports (Pazdernik et al. 1997). From this set, we selected 42 accessions which had shown resistance to pathotype 1a, 7 (race 3) of $P$. sojae. In addition, we arbitrarily chose 487 accessions with no prior $P$. sojae screening data to bring our $G$. soja sample size to a total of 529 accessions. Seed for all G. max and G. soja accessions was obtained from the United States Department of Agriculture (USDA) Soybean Germplasm Collection, increased at Virginia Tech, and screened at the Robertson Lab at Iowa State University (ISU). All G. max and G. soja accessions were screened blindly at ISU, as described below.

Identification of potential lines for resistance to $\boldsymbol{P}$. sojae. Ten seeds of each G. max accession were grown for 7 days in 8 -oz polystyrene cups filled with coarse vermiculite at $25^{\circ} \mathrm{C}$ in the greenhouse. As described above, inoculated plants in polystyrene cups were kept in a dew chamber at $25^{\circ} \mathrm{C}$ for $24 \mathrm{~h}$ in the dark and then placed in the greenhouse. Because the hypocotyls of $G$. soja were small and difficult to inoculate using the cup assay, 10 seeds of each accession were grown on germination paper for 7 days at $25^{\circ} \mathrm{C}$ in a growth chamber in the dark. The hypocotyls of the plants were inoculated as described above; then, the inoculated plants in rolled germination paper were placed in a growth chamber for 7 days at $25^{\circ} \mathrm{C}$ in the dark. During each replication of the germplasm screening, a differential set that included Sloan was inoculated with the same source of inoculum as a control. Plants were assessed 7 days postinoculation, at which time the number of dead plants in each accession was recorded.

Table 1. Soybean differentials and corresponding Rps genes used in this study $^{\mathrm{a}}$

\begin{tabular}{lccc}
\hline Differential & Rps gene & Background & Source of $\boldsymbol{R p s}$ gene \\
\hline L88-8470 & 1a & Williams & Mukden \\
L77-1863 & 1b & Williams & Harrell \\
Williams 79 & 1c & Williams & Lee 68 \\
L93-3312 & 1d & Williams & PI 103091 \\
Williams 82 & 1k & Williams & Kingwa \\
L82-1449 & 2 & Williams & CNS \\
L83-570 & 3a & Williams & PI 86972-1 \\
L91-8347 & 3b & Williams & PI 172901 \\
L92-7857 & $3 \mathrm{c}$ & Williams & PI 340046 \\
L85-2352 & 4 & Williams & PI 86050 \\
L85-3059 & 5 & Williams & PI 91160 \\
L89-1581 & 6 & Williams & Altona \\
L93-3258 & 7 & Williams & Harosoy \\
PI 399073 & 8 & $\ldots$ & ... \\
\hline
\end{tabular}

${ }^{a}$ Genetic background and the source of each Rps gene were obtained from Dorrance et al. (2004).

Table 2. Assessment scales used in this study to evaluate the virulence of the combined mixture of Phytophthora sojae isolates used as inoculum and screen Glycine max and Glycine soja accessions for resistance to $P$. sojae

\begin{tabular}{lll}
\hline Assessment & Scale $(\%)^{\mathbf{a}}$ & \multicolumn{1}{c}{ Virulence } \\
\hline Virulence assay & $\leq 30$ & Avirulent \\
& $>70$ & Virulent \\
Resistance screening assay & 0 & $100 \%$ resistant \\
& $\leq 30$ & Strongly resistant \\
& $>30$ to $\leq 70$ & Moderately resistant \\
& $>70$ & Susceptible \\
\hline
\end{tabular}

a Percentage of dead seedlings. 
Accessions were scored as either susceptible ( $>70 \%$ of plants were dead), moderately resistant ( $>30$ to $\leq 70 \%$ of plants were dead), or strongly resistant ( $\leq 30 \%$ of plants were dead) (Table 2$)$. For each accession of G. max and G. soja, 40 seedlings were screened for resistance. For accessions that showed strong resistance, additional screenings of up to 300 seedlings of $39 \mathrm{G}$. max accessions and up to 100 seedlings of $52 \mathrm{G}$. soja accessions were performed on two to four separate occasions.

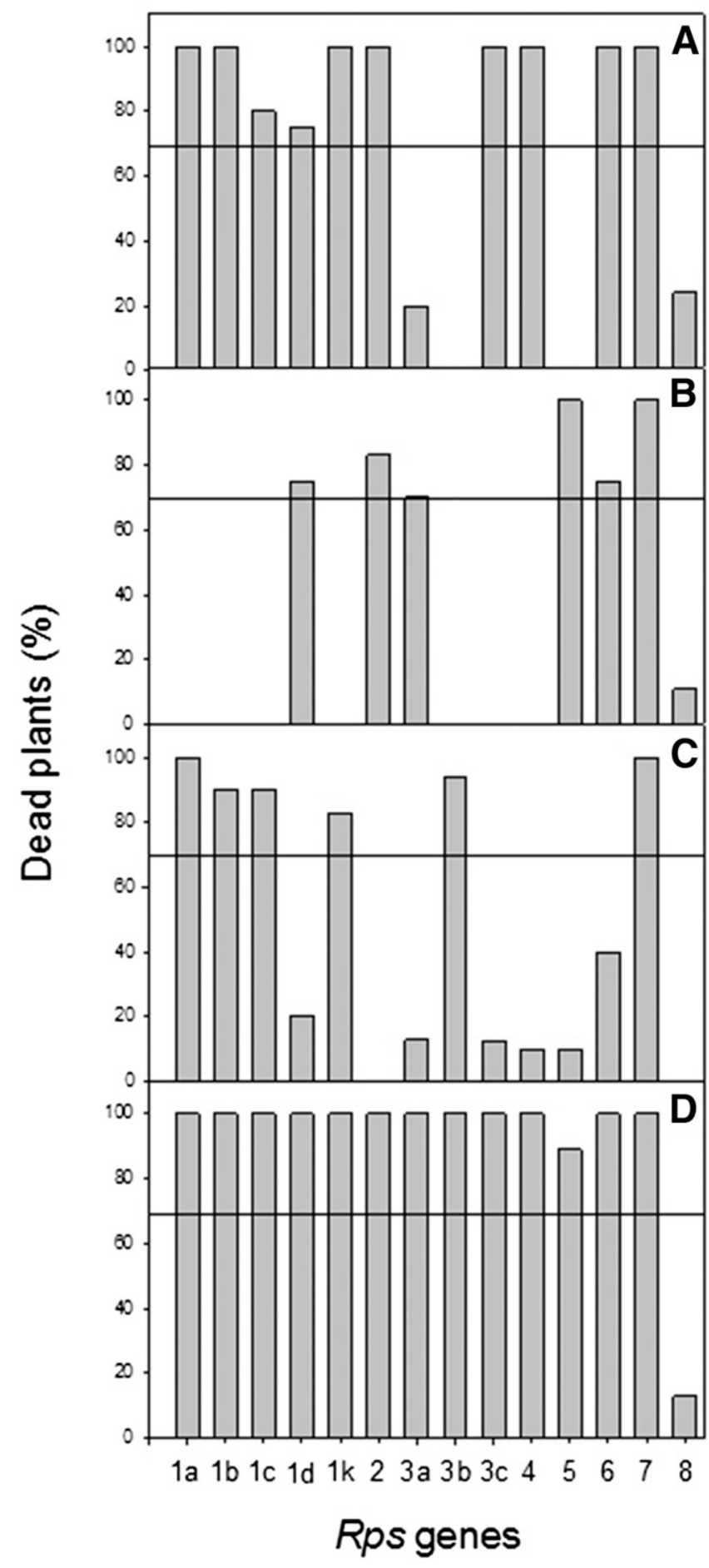

Fig. 1. Mean percentage of dead plants of soybean differentials, each containing a specific Rps gene, used to pathotype Phytophthora sojae isolates A, PT2004 C2.S1; B, R7-2a; C, 1005-2.9; and D, a 1:1:1 mixture of all three isolates. Thirty plants of each differential were inoculated and assessed. Solid line signifies $>70 \%$ of dead plants indicating virulence of the isolate or mixture on that differential.

\section{Results}

Evaluating virulence of the combined mixture of $P$. sojae isolates used as inoculum. No difference in experimental replicates was detected for PT2004 C2.S1, R7-2a, 1005-2.9, or the combined mixture $(P<0.6177,0.9975,0.2156$, and 0.3806 , respectively); therefore, disease assessment of all replicates per isolate was combined. Using the 14 differentials described in Table 1, the virulence and pathotype of each of the isolates used in this study were confirmed. Moreover, Sloan soybean, which has no Rps genes, was $100 \%$ susceptible to all three isolates (Fig. 1A to C). None of the isolates were virulent on Rps 8 under our laboratory conditions. When the differentials were inoculated with a 1:1:1 mixture of the three isolates, the mixture was virulent on all differential lines $(>70 \%$ dead plants), except PI399073, which contains the Rps 8 gene, on which it was avirulent ( $\leq 30 \%$ dead plants) (Fig. 1D). The susceptible check, Sloan, was $100 \%$ susceptible to the isolate. Thus, the pathotype of the 1:1:1 inoculum mixture was $1 \mathrm{a}, 1 \mathrm{~b}, 1 \mathrm{c}, 1 \mathrm{~d}, 1 \mathrm{k}, 2,3 \mathrm{a}$, 3b, 3c, 4, 5, 6, 7 (Fig. 1D).

Screening G. max and G. soja accessions for resistance to $\boldsymbol{P}$. sojae. The mixed-inoculum method was used to screen lines of $G$. max and $G$. soja for potential novel sources of resistance to $P$. sojae. No difference in replicates was detected for either $G$. max or $G$. sojae ( $P<0.1768$ and 0.2603 , respectively); therefore, disease assessment of all replicates per species was combined. Of the 490 G. max accessions screened, 325 lines were susceptible ( $>70 \%$ dead plants), 82 lines displayed moderate resistance ( $>30$ to $\leq 70 \%$ dead plants), and 83 lines exhibited strong resistance ( $\leq 30 \%$ dead plants). Moreover, 1 of these 83 lines was $100 \%$ resistant; in other words, no plants died as a result of being inoculated with the 1:1:1 mixture of the P. sojae isolates (Fig. 2A). Of the 529 G. soja accessions screened, 384 lines were susceptible ( $>70 \%$ dead plants) to infection, 85 lines were moderately resistant ( $>30$ to $\leq 70 \%$ dead plants), and 60 lines were strongly resistant ( $\leq 30 \%$ dead plants), with 13 of those 60 lines being $100 \%$ resistant (Fig. 2B).

\section{Discussion}

In this study, we combined agar-based cultures of three $P$. sojae isolates in a 1:1:1 single agar-based slurry and identified 83 G. max and $60 \mathrm{G}$. soja resistant accessions based on the criterion of $\leq 30 \%$ dead plants (Supplementary Table S1). It is expected that the most resistant accessions among this set have either Rps 8 or a novel Rps gene or genes. Although the number of identified resistant accessions may seem more than what would be expected, the majority of accessions we screened had been previously identified as having resistance to P. sojae (http://www.ars-grin.gov). Moreover, it is possible that some of the accessions screened were duplicates, because these are known to exist within the USDA Soybean Germplasm Collection. For example, Song et al. (2012) reported that 23 and $30 \%$ of the USDA accessions are redundant for $G$. max and $G$. soja, respectively, based on analysis with more than 42,000 single-nucleotide polymorphisms. All accessions identified as being resistant in our study were screened at least twice and sometimes up to four times, and consistently showed strong resistance ( $\leq 30 \%$ plants dead after inoculation with $P$. sojae). In addition, $1 G$. max and 13 G. soja lines were $100 \%$ resistant (no plants dead), providing strong evidence of the presence of a novel Rps resistance gene or genes.

The distribution of $P$. sojae resistance in the G. max and G. soja accessions we screened was similar. $G$. soja is a wild relative of soybean and it may be argued that more diversity in resistance might have been expected, particularly because the genetic basis of current soybean cultivars is somewhat limited. Because we did not assay all available $G$. soja accessions and the G. $\max$ accessions we screened were not arbitrarily chosen but selected based on prior studies, it is possible that we were not able to detect this greater diversity in $G$. soja.

Combining three isolates of $P$. sojae that were virulent on many of the known Rps genes was an effective method of quickly screening soybean accessions for novel sources of resistance of the pathogen. Including a set of soybean differentials and a susceptible control (i.e., Sloan) in each screening experiment was important to ensure that the mixture of inoculum was virulent on all Rps genes. Using this 
method, we consistently identified accessions that have potential novel sources of resistance to $P$. sojae. It is important to note that the Robertson Lab screened all accessions blindly; data were sent to the Maroof Lab, where accessions were chosen for retesting and sent back to ISU with a new identifier.

The genome of $P$. sojae is very plastic (Dong et al. 2011; Tyler et al. 1995) and the pathogen often evolves to overcome deployed Rps genes (Dorrance et al. 2003; Stewart et al. 2014). The extent of virulence diversity of $P$. sojae varies from state to state. For example, pathotype diversity is low in Iowa (Robertson et al. 2009) when compared with other states such as Ohio (Dorrance et al. 2003), Minnesota (Nelson et al. 1996), or Illinois (Malvick and Grunden 2004). Therefore, the importance of finding and implementing novel sources of resistance to $P$. sojae to manage PRR is economically important to soybean production in the United States. Because no one isolate of $P$. sojae has been recovered from the field that can overcome all Rps genes (Gordon et al. 2007), combining $P$. sojae isolates to make a source of inoculum covering all known Rps genes should be useful for screening soybean lines that may have multiple or novel Rps genes.

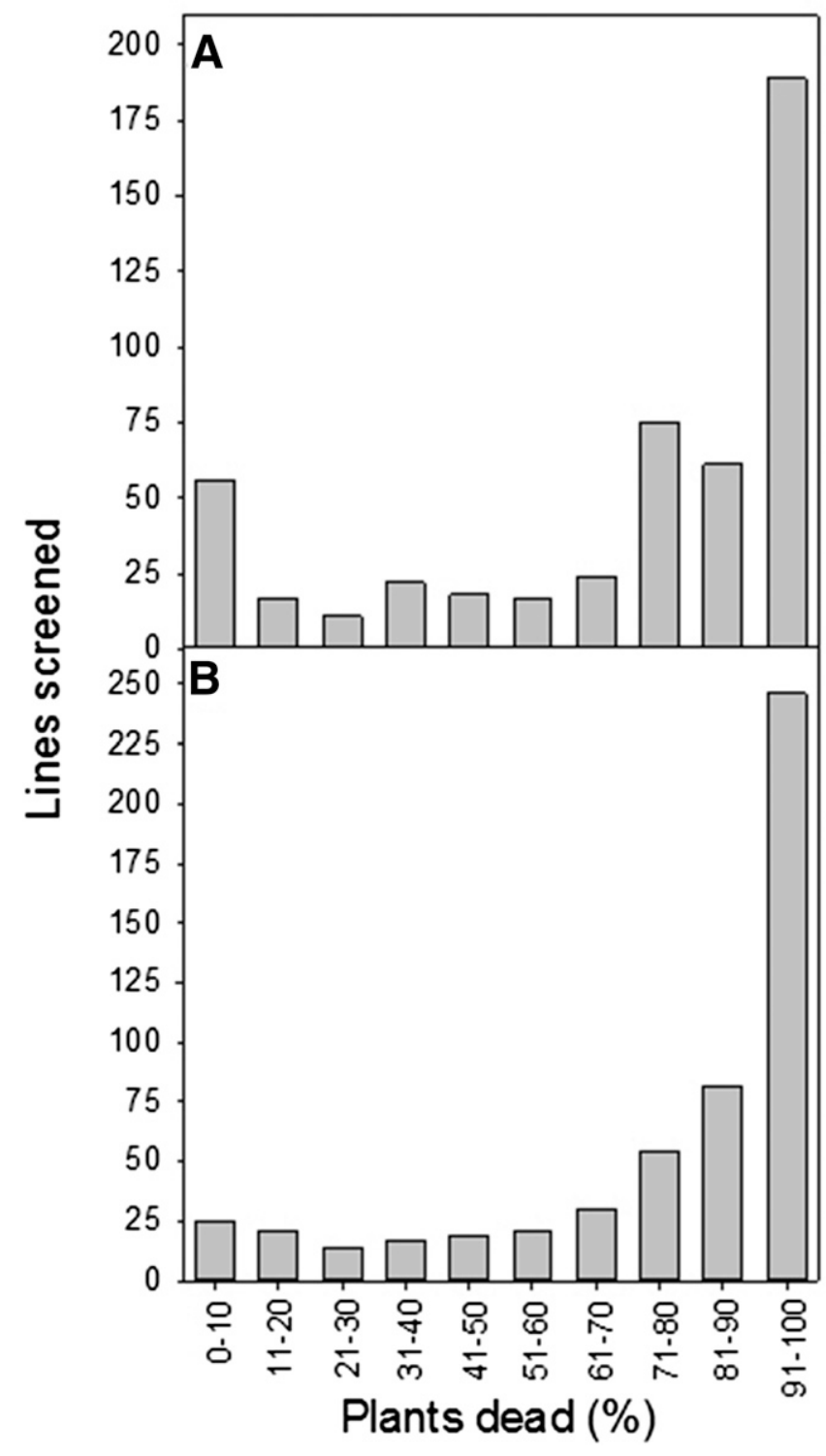

Fig. 2. Number of A, Glycine max and B. G. soja lines screened for resistance using a 1:1:1 mixture of Phytophthora sojae isolates PT2004 C2.S1, R7-2a, and 1005-2.9. Forty seedlings of each G. max and G. sojae line were screened initially. Lines showing strong resistance ( $\leq 30 \%$ dead plants) were screened two to four additional times (up to 300 and 100 seedlings for G. max and G. sojae, respectively).
Extensive surveys of $G$. $\max$ accessions for reaction to $P$. sojae have been conducted by many investigators in the past. However, screening of $G$. soja germplasm has been very limited (Pazdernik et al. 1997). Our work included the majority of the G. soja accessions available at GRIN and identified 60 resistant accessions, 13 of which showed $100 \%$ resistance to $P$. sojae. These accessions could be used in breeding programs to develop germplasm with resistance to PRR. In our study, we identified G. max and G. soja lines with potentially novel Rps genes with resistance to $P$. sojae that are potentially valuable sources of resistance in field isolates that are virulent on the most commonly deployed Rps genes. Research is currently underway to determine which of these lines recognize core RXLR effectors that are broadly conserved and essential for virulence.

In conclusion, this study is novel in that we demonstrated that isolates of $P$. sojae varying in pathotype could be combined and used as a single source of inoculum to effectively screen soybean germplasm for novel sources of resistance to the pathogen using the hypocotyl method. This method significantly reduces time, labor, space, and materials normally associated with screening germplasm and, therefore, is extremely cost effective.

\section{Acknowledgments}

We thank A. Dorrance and B. Tyler for providing two of the P. sojae isolates used in this study; J. McDowell for critically reviewing a draft of this manuscript; and USDA National Institute of Food and Agriculture, Agriculture and Food Research Initiative Competitive Grant number 2011-68004-30104 'Integrated management of oomycete diseases of soybean and other crop plants', the United Soybean Board, and the Iowa Soybean Association for providing funding.

\section{Literature Cited}

Fan, A.-Y., Wang, X.-M., Fang, X.-P., Wu, X.-F., and Zhu, Z.-D. 2009. Molecular identification of Phytophthora resistance gene in soybean cultivar Yudou 25. Acta Agron. Sin. 35:1844-1850.

Burnham, K. D., Dorrance, A. E., Francis, D. M., Fioritto, R. J., and St. Martin, S. K. 2003. Rps 8, a new locus in soybean for resistance to Phytophthora sojae. Crop Sci. 43:101-105.

Demirbas, A., Rector, B., Lohnes, D., Fioritto, R., Graef, G., Cregan, P., Shoemaker, R., and Specht, J. 2001. Simple sequence repeat markers linked to the soybean Rps genes for Phytophthora resistance. Crop Sci. 41:1220-1227.

Diers, B., Mansur, L., Imsande, J., and Shoemaker, R. 1992. Mapping Phytophthora resistance loci in soybean with restriction fragment length polymorphism markers. Crop Sci. 32:377-383.

Dong, S., Yu, D., Cui, L., Qutob, D., Tedman-Jones, J., Kale, S. D., Tyler, B. M., Wang, Y., and Gijzen, M. 2011. Sequence variants of the Phytophthora sojae RXLR effector Avr3a/5 are differentially recognized by Rps 3 a and Rps 5 in soybean. PLoS One 6:e20172.

Dorrance, A., Mills, D., Robertson, A., Draper, M., Giesler, L., and Tenuta, A. 2007. Phytophthora root and stem rot of soybean. Online publication. Plant Health Inst. doi:10.1094/PHI-I-2007-0830-07

Dorrance, A. E., Jia, H., and Abney, T. S. 2004. Evaluation of soybean differentials for their interaction with Phytophthora sojae. Online publication. Plant Health Prog. doi:10.1094/PHP-2004-0309-01-RS

Dorrance, A. E., McClure, S. A., and deSilva, A. 2003. Pathogenic diversity of Phytophthora sojae in Ohio soybean fields. Plant Dis. 87:139-146.

Dorrance, A. E., Robertson, A. E., Cianzo, S., Giesler, L. J., Grau, C. R., Draper, M. A., Tenuta, A. U., and Anderson, T. R. 2009. Integrated management strategies for Phytophthora sojae combining host resistance and seed treatments. Plant Dis. 93:875-882.

Dorrance, A. E., and Schmitthenner, A. F. 2000. New sources of resistance to Phytophthora sojae in the soybean plant introductions. Plant Dis. 84:1303-1308.

Gordon, S. G., Berry, S. A., St. Martin, S. K., and Dorrance, A. E. 2007. Genetic analysis of soybean plant introductions with resistance to Phytophthora sojae. Phytopathology 97:106-112.

Gordon, S. G., St. Martin, S. K., and Dorrance, A. E. 2006. Rps8 maps to a resistance gene rich region on soybean molecular linkage group F. Crop Sci. 46:168-173.

Grau, C. R., Dorrance, A. E., Russin, J., and Bond, J. 2004. Fungal diseases. Pages 679-763 in Soybeans: Improvement, Production, and Uses. H. R. Boerma and J. E. Specht, eds. American Society of Agronomy, Crop Science Society of America, Soil Science Society of America, Inc., Madison, WI.

Jiang, R. H., and Tyler, B. M. 2012. Mechanisms and evolution of virulence in oomycetes. Annu. Rev. Phytopathol. 50:295-318.

Kaufmann, M. J., and Gerdemann, J. W. 1958. Root and stem rot soybean caused by Phytophthora sojae n. sp. Phytopathology 48:201-208.

Koenning, S. R., and Wrather, J. A. 2010. Suppression of soybean yield potential in the continental United States by plant diseases from 2006 to 2009. Online. Plant Health Progress doi:10.1094/PHP-2010-1122-01-RS. 
Lin, F., Zhao, M., Ping, J., Johnson, A., Zhang, B., Abney, T. S., Hughes, T. J., and Ma, J. 2013. Molecular mapping of two genes conferring resistance to Phytophthora sojae in a soybean landrace PI 567139B. Theor. Appl. Genet. 126:2177-2185.

Lohnes, D., and Schmitthenner, A. 1997. Position of the Phytophthora resistance gene Rps 7 on the soybean molecular map. Crop Sci. 37:555-556.

Malvick, D. K., and Grunden, E. 2004. Traits of soybean-infecting Phytophthora populations from Illinois agricultural fields. Plant Dis. 88:1139-1145.

May, K. J., Whisson, S. C., Zwart, R. S., Searle, I. R., Irwin, J. A. G., Maclean, D. J., Carroll, B. J., and Drenth, A. 2002. Inheritance and mapping of 11 avirulence genes in Phytophthora sojae. Fungal Genet. Biol. 37:1-12.

Nelson, B. D., Hansen, J. M., and Windels, C. E. 1996. Races of Phytophthora sojae on soybeans in the Red River Valley of Minnesota and North Dakota. Plant Dis. 80:104.

Pazdernik, D. L., Hartman, G. L., Huang, Y. H., and Hymowitz, T. 1997. A greenhouse technique for assessing Phytophthora root rot resistance in Glycine max and G. soja. Plant Dis. 81:1112-1114.

Robertson, A. E., Cianzio, S. R., Cerra, S. M., and Pope, R. O. 2009. Within-field pathogenic diversity of Phytophthora sojae in commercial soybean fields in Iowa. Online publication. Plant Health Prog. doi:10.1094/PHP-2009-0908-01-RS

Sandhu, D., Schallock, K., Rivera-Velez, N., Lundeen, P., Cianzio, S., and Bhattacharyya, M. 2005. Soybean Phytophthora resistance gene Rps 8 maps closely to the Rps3 region. J. Hered. 96:536-541.

Schmitthenner, A. F. 1985. Useful methods for studying Phytophthora in the laboratory. OARDC Spec. Circ. 143.

Slaminko, T. L., Bowen, C. R., and Hartman, G. L. 2010. Multi-year evaluation of commercial soybean cultivars for resistance to Phytophthora sojae. Plant Dis. 94:368-371.

Song, Q., Hyten, D., Jia, G., Nelson, R., Quigley, C., Fickus, E., and Cregan, P. 2012. Status of the soybean HAPMAP and the structure of high-resolution haplotype blocks in the soybean genome. In: Molecular and Cellular Biology of the Soybean, 14th Biennial Conf. Des Moines, IA.

Song, T., Kale, S. D., Arredondo, F. D., Shen, D., Su, L., Liu, L., Wu, Y., Wang, Y., Dou, D., and Tyler, B. M. 2013. Two RxLR avirulence genes in Phytophthora sojae determine soybean Rps 1k-mediated disease resistance. Mol. Plant-Microbe Interact. 26:711-720.

Staskawicz, B. J., Ausubel, F. M., Baker, B. J., Ellis, J. G., and Jones, J. D. G. 1995. Molecular genetics of plant disease resistance. Science 268:661-667.
Stewart, S., Abeysekara, N. S., and Robertson, A. E. 2014. Pathotype and genetic shifts in a population of Phytophthora sojae under soybean cultivar rotation. Plant Dis. 98:614-624.

Sugimoto, T., Kato, M., Yoshida, S., Matsumoto, I., Kobayashi, T., Kaga, A. Hajika, M., Yamamoto, R., Watanabe, K., Aino, M., Matoh, T., Walker, D. R., Biggs, A. R., and Ishimoto, M. 2012. Pathogenic diversity of Phytophthora sojae and breeding strategies to develop Phytophthora-resistant soybeans. Breed. Sci. 61:511-522.

Sun, S., Wu, X. L., Zhao, J. M., Wang, Y. C., Tang, Q. H., Yu, D. Y., Gai, J. Y., and Xing, H. 2011. Characterization and mapping of Rps $Y u 25$, a novel resistant gene to Phytophthora sojae. Plant Breed. 130:139-143.

Tyler, B. M. 2007. Phytophthora sojae: Root rot pathogen of soybean and model oomycete. Mol. Plant Pathol. 8:1-8.

Tyler, B. M. 2009. Entering and breaking: Virulence effector proteins of oomycete plant pathogens. Cell. Microbiol. 11:13-20.

Tyler, B. M., Forster, H., and Coffey, M. D. 1995. Inheritance of avirulence factors and restriction-fragment-length-polymorphism markers in outcrosses of the oomycete Phytophthora sojae. Mol. Plant-Microbe Interact. 8:515-523.

Wang, H., St. Martin, S. K., and Dorrance, A. E. 2012. Comparison of phenotypic methods and yield contributions of quantitative trait loci for partial resistance to Phytophthora sojae in soybean. Crop Sci. 52:609-622.

Weng, C., Yu, K., Anderson, T., and Poyosa, V. 2001. Mapping genes conferring resistance to Phytophthora root rot of soybean, Rpsla and Rps7. J. Hered. 92: 442-446.

Wu, X.-L., Zhang, B.-Q., Sun, S., Zhao, J.-M., Yang, F., Guo, N., Gai, J.-Y., and Xing, H. 2010. Identification, genetic analysis and mapping of resistance to Phytophthora sojae in Pm28 in soybean. Agric. Sci. China 10: 1506-1511.

Zhang, J., Xia, C., Duan, C., Sun, S., Wang, X., Wu, X., and Zhu, Z. 2013 Identification and candidate gene analysis of a novel Phytophthora resistance gene Rps10 in a Chinese soybean cultivar. PLoS One 8:e69799.

Zhang, S. Z., Xu, P. F., Wu, J. J., Xue, A. G., Zhang, J. X., Li, W. B., Chen, C. Chen, W. Y., and Lv, H. Y. 2010. Races of Phytophthora sojae and their virulences on soybean cultivars in Heilongjiang, China. Plant Dis. 94:87-91.

Zhu, Z., Huo, Y., Wang, X., Huang, J., and Wu, X. 2007. Molecular identification of a novel Phytophthora resistance gene in soybean. Acta Agron. Sin. 33: 154-157. (In Chinese) 